\title{
THE UK AND EUROPEAN “CENTRE FORMATION” FROM 1950 TO BREXIT
}

\author{
CHRISTOPHER LORD \\ christopher.lord@arena.uio.no \\ ARENA - Centre for European Studies, \\ Faculty of Social Sciences, \\ The University of Oslo
}

\begin{abstract}
It might be thought that Brexit is just a case of the UK getting honest with itself and its partners. On that interpretation, much British opinion never really accepted European integration. Hence, the UK should never have joined a body committed to an "ever closer Union between the peoples of Europe." Yet, I argue, the relationship of the UK to the process of European integration has been complex and paradoxical. As a member of the EU, the UK promoted a major act of European centre formation: namely, the formation of the single market. Even where they felt unable to participate in other initiatives - such as monetary union and Schengen - British Governments settled for largely constructive forms of abstention. One thing the UK has not been is a significant constraint, or source of fragmentation in the process of European integration. That may not even change with the vote in June 2016 to leave the Union. Continued UK participation in aspects of European integration cannot be ruled out. Nor can a failed exit from the Union. On the one hand, Brexit seems both necessary and impossible: something the UK has to do and something that it cannot do. On the other hand, there seems to be no stable equilibrium in British politics for any one approach to Brexit. Yet, if it cannot "exit," the UK may have to seek more "voice" and "loyalty" in its relationship with the Union. I make this argument by reviewing some of the history and contemporary political science of the UK's relationship with the European Union in what, I hope, are mutually helpful ways.
\end{abstract}

Keywords: Brexit; integration; disintegration; differentiated integration; segmentation.

How to cite: Lord, Christopher (2018). "The UK and European 'Centre Formation' from 1950 to Brexit," Geopolitics, History, and International Relations 10(1): 46-78.

Received 26 February $2017 \cdot$ Received in revised form 3 September 2017 Accepted 5 September 2017 • Available online 27 September 2017 


\section{Introduction}

On the morning of 24 June 2016 it became impossible for the "remain" vote in the referendum on the UK's continued membership of the Union to overtake the "leave" vote. For the first time, a member state had voted to leave the Union. Almost exactly sixty-six years earlier the then British Government spent much of June 1950 assessing whether it had made the right call in rejecting an offer to take part in the talks that led to the original European Coal and Steel Community. Amongst those assessments was, interestingly in hindsight, a warning the UK should not join a process of European integration that it might one day have to leave. ${ }^{1}$ Later, it would become more common in British Government circles to claim that any European integration could only happen on terms acceptable to the UK, and that controlling the process from within was an important argument for joining it (UK Government, 1971). But that still lay in the future. In 1950, The UK Foreign Office described the proposed ECSC authority as "a step towards a federation" and a "prototype of federal institutions in Europe." It cautioned that Britain's acceptance would be "interpreted as an expression of our attitude towards a federal Europe." Ministers should only participate if they were prepared to continue the federal journey: to be "hustled along the road to full federation through the creation of supranational authorities controlling a widening range of functions.",

Yet it was Churchill who most memorably expressed the view that the UK could only participate up to a point in any process of European integration. As he put it, "we are with but not of Europe." He told his government: "we help, we dedicate, we participate, but we do not merge or forfeit our insular character." Some even doubted that it would always be wise to "help." Sir Gledwyn Jebb, the Permanent Secretary at the Foreign Office, would scribble "embrace destructively" when confronted with an early proposal for a Common Market (Horne, 1988: 363).

It is easy to tell the story of Britain's relationship with European integration as a comedy of errors (Massigli, 1978) errors from beginning to end. On the day in 1950 the Cabinet had to decide whether the UK was to participate in the talks on the Schuman Plan, all three of the most senior members of the Government - the Prime Minister (Attlee), the Foreign Secretary (Ernest Bevin), and the Chancellor of the Exchequer (Stafford Cripps) - were in hospital. From his hospital bed, Bevin advised, in a fabulous mixing of metaphors, that the UK should not "buy a pig in a poke," nor should it open "Pandora's box" lest a whole lot of "Trojan horses jump out" (Bullock, 1983: 659). Fifty years later the UK's relationship with the European Union still seemed accident prone. In 2009, Gordon Brown arrived late for the signing of the Lisbon Treaty, which he then had to sign in a room on his own. Whilst Brown insisted there had been a "diary clash" (Seldon \& Lodge, 2010: 68), others suspected he did not want to supply the tabloid press with any pictures of him signing the Treaty.

Yet anecdotes such as these only beg deeper questions. Why in 1951 did one British Prime Minister believe that the UK could not participate in European integration in a manner that "forfeited its insular character"; and why, in 2009, did 
another British Prime Minister believe it would be unpopular - and perhaps even perceived as wrong - to be pictured signing a European Union Treaty? Behind reticence, and even opposition, to British participation in European integration were various claims that the British state, British identity, British economy, British society and Britain's international commitments were incompatible with European integration carried beyond a certain point. Of course, those claims would be made in contrasting ways over the years. From 1950 until well into the 1980s, many on the left worried that European integration would be incompatible with the ability of the UK to plan or manage its own economy. As one prominent Labour opponent of UK entry put it in the House of Commons debate in 1971 on whether the UK should join the European Communities, membership would "put locks" on prospects of socialism. ${ }^{4}$ From, the late 1980 s, however, it was supporters of radical market deregulation who were the more likely to argue that the political economy of European integration was incompatible with that of the UK. In 2016, Nigel Lawson - ex-chair of the leave campaign and Thatcher's former finance minister - would welcome the Brexit vote as removing an obstacle to finishing the Thatcher revolution (Financial Times, 2 September 2016).

However, by far the most important claim has surely been that supranational forms of European integration are somehow incompatible with British sovereignty, identity and conceptions of democratic self-government. Another British Prime Minister has endorsed just such a view. This is what Theresa May said in setting out her aims for Brexit in January 2017: "Our political traditions are different...the principle of parliamentary sovereignty is the basis of our constitutional settlement... The public expect to be able to hold governments to account very directly, and, as a result, supranational institutions as strong as those of the EU sit very uneasily in relation to our political history and our way of life" (UK Government, 2017).

Yet the full story is more ambivalent. For most of the period from 1950 to 2016, there has been much opposition in British politics to participation the formation of a new "political centre" at the European level. Yet the UK has itself supped greedily at that table. The UK has been the great Janus of European integration with one face turned inwards in opposition to the development of new forms of political rule through the institutions and policies of the European Union and another face turned outwards towards willing and creative contributions to the development of those same policies and institutions. Understanding the history of both those faces can now help us understand Brexit.

I develop that argument as follows. Section 2 explains what I mean by political centre formation at the European level, and why hostility to that possibility remained such a potent force in British politics between 1950 and 2016 that it could still provide a vote to leave the Union with its underlying coherence. Section 3 argues that aversion to European centre formation did not, however, define British membership of the European Union between 1973 and 2016. Far from it. The UK was the most enthusiastic supporter of what has, arguably, been the single most important act of European centre formation: namely the creation of the single 
market from the mid-1980s. Even in matters other than the single market, British governments reconciled their membership of the Union with its further integration by settling for largely constructive forms of differentiation in both the Union's authority relations and in the UK's participation in EU policies. That differentiation contributed far more to the development of the Union than detracted from it. Section 4 turns to the disintegration of UK membership of the Union under the pressure of the multiple crises that afflicted European integration after 2008. It shows how public opinion was initially unformed and volatile on the question of exiting the Union. Yet, the referendum itself eventually stabilized opinion into two equal and opposite forces, leaving a country deeply divided on fundamental questions of globalization and on how and how far it should withdraw from the Union. Section 5 classifies the different choices that are available to the UK after Brexit by how far they would resolve historical ambiguities in the UK's relationship European political centre formation. Section 6 questions, however, whether there is a stable equilibrium within British politics for any one of those choices; and whether the British political system - as it has been structured since the UK took its present territorial form in 1922 - is likely to survive the attempt to withdraw from the European Union.

The argument is developed, methodologically, from a review of the history of the UK's relationship with the process of European integration (sections 2-4) and of aspects of the history of the UK's own political system (section 6). However, it is important also to be able to identify just where Brexit may break from the past. Hence, section 5 develops scenarios that compare possible outcomes of Brexit by how far they would change British policies towards European integration which have been remarkably consistent since 1950 in wanting neither to abstain in full nor participate in full.

\section{Hostility to European Centre Formation}

The term "political centre formation" has perhaps most famously been used by the political scientist Stein Rokkan. What Rokkan meant by centre formation can be inferred from his three stages of state-building, nation-building and democracybuilding. State-building creates a political centre with a "unified and distinctive system of law" (Flora et al., 1999: 161) and with an administrative hierarchy capable of supervising the enforcement of those laws. Nation-building creates a political centre with the shared communications, identities, norms and obligations needed to practice politics together. Democracy-building creates a political centre where majorities can make decisions binding on all. For sure, state, nation and even democracy are concepts that are difficult to apply to a multi-state and multinational polity such as the Union that is not itself a state or a nation. Yet, the EU has many components of political centre formation. First, Union law takes priority over national law. Second, the Union has its own executive order which can accumulate expertise, supervise the enforcement of policies and set the legislative agenda (Curtin 
and Egeberg, 2008). Third, majorities of the Council - and of an independently elected European Parliament - can make decisions binding on all member states. Fourth, non-state actors - both individuals and organized interests - often deal directly with Union institutions without mediation of their own national governments. Finally, membership of the Union has often been understood - albeit in a way that has never been fully specified beyond the deliberately ambivalent treaty commitment to "ever closer union between the peoples of Europe" (Treaty on European Union, Article 1) - as an aspiration to form some kind of a new political centre at the European level with its own policies, institutions and identity.

For sure, different people have meant different things in claiming that membership of the EU is somehow incompatible with national identity, sovereignty or conceptions of what it is for the UK to govern itself free from outside interference. But the following is one possible historical reconstruction of why participation in European integration has been so neuralgic in British politics. Threats of invasion and, therefore, outside rule - were central to the formation of English and later British identity (Colley, 1992). Opposing a concentration of power on the continent was the principal external purpose of the British state formed after 1707 by the Union of England and Scotland. The sovereignty of its parliament and the supremacy of its laws were the main internal characteristics of the British polity. "England is an Empire... with plenary, whole and entire power" proclaims the Act in Restraint of Appeals of 1533. Nor is this ancient history. One of the leading campaigners in the Conservative Party to leave the EU has an essay in his on-line diary on the role of Henry VIII's legislation in establishing the sovereignty of the British state (Redwood, 2012). Then, of course, there has always been the latent tension between supremacy of EU law and the sovereignty of the Westminster Parliament. As famously summarized by Dicey (1885) "the principle of parliamentary sovereignty means neither more nor less than this, namely that Parliament has, under the English (sic) constitution, the right to make and unmake any law whatever; and, further, that no person or body is recognized by the law of England as having a right to override or set aside the legislation of Parliament." Hence, in entering the European Communities in 1973, the UK needed in a curious way to anticipate Brexit. Sir Geoffrey Howe, then Solicitor-General, told the House of Commons in 1972: "The acceptance of Community law within the restrictions of the treaties...is consistent with the sovereignty of Parliament and its ultimate power in principle to repeal the bill." ${ }^{5}$ Repealing the bill would, of course, entail exiting.

Concepts of British identity were no easier than concepts of British sovereign statehood to reconcile with membership of the European Communities. After 1945, many in Britain would find it hard to define their attitudes to European unification without recalling how close the UK had come to invasion from continental Europe in 1940-1. Few would go as far as the cabinet minister who was forced to resign in 1990 after claiming that the European Union was achieving through peace what Hitler had failed to achieve through war. But concern that European integration could amount to a form of external domination was plainly a part of British Euroscep- 
ticism, whether that was scepticism about the very idea of European unification, British participation in it, or any EU policies or institutions that might corrode national identity or elude the control of individual member states.

Perhaps the nearest parallels are in East and Central Europe. There too historic memories do not give a clear run to the claim that supranational institutions can limit conflict between European states. Rather, historic experience also allows supranational institutions to be framed as external impositions. ${ }^{6}$ The point, of course, is not that voluntary participation in the Union is in any way the same as the imposed rule that East and Central Europe suffered in 1945-1989 and the UK narrowly escaped in 1940-1. It is merely those historical experiences create unusual sensitivities to any aspects of European integration that can even be remotely interpreted as external domination. Governments and many political parties have had to reckon with even small pockets of opinion that can be mobilised around claims that some part of what the Union does is an illegitimate form of external rule.

Indeed, history may lend itself even more to opposing European integration in the UK than in East and Central Europe. Unlike East and Central European countries, the UK was one of the few European states that emerged from the crisis of 191445 without being defeated, invaded or discredited by war. Even the idea of parliamentary sovereignty weathered the storm. The UK was one of only five European states in which parliamentary democracy survived uninterrupted between 1918 and 1945 (Hobsbawm, 1994: 111). After 1945 attachment to national parliamentary sovereignty only seemed to grow stronger. The Labour and Conservative parties both mythologised parliamentary sovereignty. Both parties valued parliamentary sovereignty as a formidable instrument of social transformation which, in their own self-understanding, they had heroically used to shape their country in their own image: leftwards, in the case of the Labour Party, between 1945 and 1951, rightwards, in the case of the Conservative Party, between 1979 and 1990. For neither party was parliamentary sovereignty to be given up lightly.

All this history constrained what British governments felt able to agree as members of the Union. The point is well illustrated by a series of studies (Marcussen et al., 1999; Risse et al., 1999) into why French and German elites largely supported monetary union whilst British elites declined participation:

Differences in the construction of collective elite identities pertaining to the nation state and to Europe explain the controversies between elites in the three countries as well as variation in attitudes. While the French and German elites - from the centre-left to the centre-right - have incorporated Europe into their collectively defined identities, British policymakers including new Labour remain hesitant (1999: 148-9).

Moreover, the authors found, perceived interests did not counter the influence of historically-conditioned identities. To the contrary, "collective national identities" defined the "range of instrumental or material interests" that were considered 
"legitimate" to assessments of whether the UK should participate in the single currency (ibid.).

Nor was British public opinion at ease with UK's membership. McLaren (2004: 898) has used Eurobarometer data to show that fear European integration might lead to a loss of national identity is quite common across the Union. Yet, intriguingly, that fear does not usually lead to opposition to European integration. The UK is one of the member states where it does. Moreover, Eurobarometers have shown that UK citizens are amongst the least likely to have heard of the Council of Ministers of the EU. That detail is crucial. Those who are aware of the Council of Ministers are more likely to be aware that their own government participates in Union decisions. Indeed, most Council decisions are taken with the agreement of all governments even where majority voting is possible (Mattila \& Lane, 2001; Mattila, 2009). Those who are unaware of the Council of Ministers are, conversely, more likely to understand Union decisions as external impositions (Lord, 2004: 57).

If historical understandings of identity, nationhood, statehood and of the legitimacy of participation in forms of shared rule beyond the state coexisted uneasily with the UK's membership of the EU, they seem to be no less important to the manner of its leaving the Union. Differences in how far it is believed to be right for the UK to participate in the making of shared policies and shared laws beyond the state shape Brexit, who is for it, who against it, and ways in which it might be attempted. When asked in a YouGov survey to pick "the most important issues when deciding on Britain's future relationship with the EU," $54 \%$ of all leave voters chose "ensuring Britain has control over its own laws" as an answer. In contrast, that response was chosen by only $17 \%$ of remain voters. That does not mean remain voters consider the control of laws unimportant. It may just be that remain voters are less likely than leave voters to believe that the UK ever lost control of its own laws to the EU or - dare one say it - that they believe the EU is a broadly fair way of sharing out control of laws between countries which choose to make some of their laws together. All those are fascinating and important matters for further research. For the moment, we only need to note that leave versus remain is a legitimacy cleavage. Many leavers believe that Brexit is justified by a need for the UK to regain control of its own laws. Many remain voters seem unconvinced that is a sufficient justification for Brexit.

Indeed, belief that Brexit is about regaining control and returning the UK to rule by its own government, parliament and voters provides the underlying unity of the Brexit vote. Failure to understand that risks failure to understand the June 2016 referendum. For sure, it is often noted that Brexit is the product of an inconsistent coalition. And in many ways it is. Many of its strategists and policy entrepreneurs are libertarians and market fundamentalists who see Brexit as an opportunity to turn the UK into one of the most de-regulated economies in the world. Many Brexit voters, on the other hand, supported Brexit as a protest precisely against those forms of unregulated globalisation and movements of labour that may be needed for the UK to prosper as a highly competitive and fully internationalised economy 
outside the EU. As Weale has noted, the campaign to leave the European Union was "never, and (could not) be one consistent alternative. (Leave) was a portmanteau term for a number of mutually inconsistent alternatives" (2017: 7). Yet, whatever their contradictions, most supporters of Brexit would probably agree that they voted in some way for the UK to "take back control of its own laws, money and borders." Once again, Weale puts the point well:

\begin{abstract}
Those favouring Brexit often argued a purely political case. The footsoldiers of the leave campaign were concerned with something other than the economics of comparative advantage. 'Take back control' and 'we want our country back' are pre-eminently the principles of engaged democratic citizens. Many leavers thought themselves to be fighting for a cause greater than the standard of living... Instead they thought in terms of parliamentary representatives determining the common political life in the UK (2017: 4).
\end{abstract}

The point is amply confirmed by a huge survey of 12639 voters directly after they had voted on referendum day itself. The idea of "regaining control" dominated over any other reason for voting to leave the EU. 49\% of those who voted leave said their main reason for doing so was "the principle that decisions about the UK should be taken by the UK." $33 \%$ said the main reason was that the UK would be able to "regain control of immigration and its own borders." A mere $6 \%$ felt that "when it comes to trade and the economy, the UK would benefit more from being outside the Union than within it" (Ashcroft, 2016).

\title{
3. UK Membership of the EU and European Political Centre Formation: 1973-2008
}

Given the UK's attachment to the sovereignty of its own parliament and the supremacy of its own laws, its historic wariness of any concentration of power on the European continent, and its self-confidence (except in the 1960s and 1970s) in the capacities of its own state, it was easy to anticipate that, once a member, the UK would constrain European integration and perhaps even fragment the Union. In January 1963, the French President, Charles de Gaulle, memorably vetoed British accession on the grounds the UK would be a "Trojan horse." When, in 1969, the six original members re-opened negotiations with the UK it was not without taking the precaution of first committing the UK to existing and further integration (Simonian, 1984; De La Serre, 1987), lest it should seek to unravel it. Then, when the UK joined in 1973, it seemed to confirm fears that it would disrupt the Communities. It spent much of the first decade of its membership seeking to renegotiate the terms of its accession. The first change of Government in 1974 brought in a Labour administration committed to a wholesale renegotiation. The next change in 1979 brought in a Conservative Government which refused to agree to any major 
new initiative within the European Communities until it received a rebate on its budget contribution in 1984 .

Throughout its membership, the UK also supported the enlargement of the EU, in part, it was suspected, because a wider European Union would be less likely to be a deeper one; or, as the joke went, if enough states could be persuaded to jump on board, the raft would eventually sink. ${ }^{7}$ Indeed, it seemed obvious to many that the best way of avoiding awkward choices, given its attachment to the sovereignty of its own parliament and the supremacy of its own laws, would be for the UK simply to prevent integration proceeding too far.

There was, however, one thing any expectation the UK might constrain integration from within could not survive: namely, the UK itself and its own paradoxical appetite for some kinds of integration. Once the early crises in its membership were behind it, the UK sought some way of permanently improving its relationship with the EC through its support for the single market initiative. That, in turn, made a decisive contribution to European centre formation. Although the European Communities were founded in the $1950 \mathrm{~s}$, there is much to the argument that there was rather little to European integration before the mid-1980s (Bickerton, 2012). The single market initiative changed all that. It switched efforts from removing at border barriers to trade to remove those behind boundaries. That, in turn, required a massive volume of shared law-making. Whilst, then, the European Court of Justice had first claimed the supremacy of EC law in 1964, it was only in the late 1980s that member states began to use their shared membership of the EC to legislate together on an ambitious scale. From the launch of the single market programme in 1986, the European Union became a significant form of shared rule. From then on member states made large volumes of law together. The allocation of values in each member state and the lives of citizens of each member state were now significantly affected by laws their governments made through their shared membership of the Union. No member state pushed harder for the single market than the UK. The extent of British support for the single market - and of awareness in the British Government that it would entail further European centre formation - is clear from Thatcher's memoirs:

I had one overriding positive goal. This was to create a single market... What remained were so-called non-tariff barriers. The price which we would have to pay to achieve a single market with all its economic benefits was more majority voting in the Community. There was no escape from that, because otherwise particular countries could succumb to domestic pressures and prevent the opening up of their markets. It also required more power for the European Commission (1993: 553).

Still more surprisingly, the UK also contributed in several ways to what so many expected it to oppose: namely, the development of the EU as an original form of political authority for managing relations between democratic states. Each contribution was paradoxical but real all the same. First, the UK promoted the development of the so-called Union method (Bickerton et al., 2015). Summarised simply, 
the difference between the Community and Union methods is as follows. Under the Community method, the Commission exercises an exclusive right of initiative. The Council formally decides by Qualified Majority. The European Parliament normally gets to co-decide. The European Court of Justice has competence. In contrast, under the Union method, the Commission often participates in decisions. But it has no exclusive right of initiative. The Council normally decides by unanimity. The Parliament is only consulted or informed. The Court of Justice is often excluded from jurisdiction (op. cit., 3).

For sure, UK support for the Union method - most famously during the negotiation of the Treaty on European Union (1992) - has frustrated the development of the EU into a single political system with a singular form of political authority based on the Community method. However, to reply to that objection, the Union and Community methods do not usually compete with one another. Rather, they do different things. The Community method makes law in matters where the Union has competence. The Union method mostly co-ordinates national powers through the institutions of the Union. Whilst the Union method requires the unanimous agreement of member states - and can do no other given that it co-ordinates the powers of member states - that unanimous agreement is crucially formed in the institutions of the European Union. It is agreed in the European Council/Council. It is often also co-ordinated with decisions under the Community method. It often draws on the expertise and participation of the Commission.

That particular institutional configuration contained in the Union method has with steadily growing importance since 1992 - allowed the Common Foreign and Security Policy to co-ordinate security missions and security capabilities in ways that go beyond the largely declaratory character of early attempts at foreign policy co-operation (Hill, 1993). It has also allowed Justice and Home Affairs to develop ambitious forms of information exchange in matters of internal security. It has even permitted a hybrid of the Union and Community methods to be used by the European semester (Lord, 2017) to co-ordinate the budgets - and, therefore, the taxing, spending and borrowing - of member states. All these are, as Genschel and Jachtenfuchs (2014) argue, examples of how member states co-ordinate the exercise of their core state powers through the Union where that suits them. Without a combination of monetary union which the UK did not shape and the Union method which it did shape, the EU would probably have remained the kind of regulatory state Majone (1994) claimed it to be in the 1990s: a hugely powerful instrument of market regulation, largely confined, none the less, to market regulation. In short, the UK's support for the Union method has greatly increased the scope of the Union.

Moreover, British historic conceptions of self-rule of the kind discussed in Section 2 were not just obstacles. To the contrary the challenge of adapting those conceptions to EU membership has even contributed to the wider political development of the Union. Take, the example, of a famous High Court judgement in which Lord Denning said of the EU Treaties: "The Treaty is like an incoming tide. It flows into the estuaries and up the rivers. It cannot be held back. Parliament has 
decreed that the Treaty is henceforth to be a part of our law." ${ }^{\prime 8}$ This was grudging. Indeed, Denning would end his career a supporter of the Eurosceptic revivalism of the 1990s. Yet even the Denning judgement was an example of national courts working hard to adapt national law to Union law and to avoid conflicts between the two (see also Weiler, 2005: 189). As Lindseth (2010) has argued, that is one of three ways in which member states have evolved "national legitimating mechanisms" that allow the Union to borrow their legitimacy. The UK has also promoted the other two: namely, the close involvement of elected national governments in Union decisions and scrutiny by national parliaments. The UK civil service has a formidable reputation for its oversight of Union decisions. Together with the Danish parliament, Westminster pioneered practices of national parliamentary scrutiny of Community decisions which had barely existed before 1973. In sum, then, the UK has contributed to the development of EU member states into states of a distinctive kind (Bickerton, 2012): namely, states that have adapted their own law, executives and representative institutions to their shared membership of the Union.

A final contribution to the Union's political development has, paradoxically, been via the largely constructive forms of differentiation - both in the Union's authority relations and in the participation of states in Union policies (Leruth \& Lord, 2015) - that developed in response to the difficulties of UK membership. British Governments did not seek differentiation. At first, they feared complete non-participation as much as they feared full participation in unwanted proposals for further integration. They believed the main lesson of non-membership between 1950 and 1973 was that the UK should not allow itself to be marginalized from decisions by which it would be affected or from policies it might one day have to join (Heath, 1970). Attali (1995: 876-7) recalls a conversation during the Maastricht negotiations. In response to Mitterrand's observation that "Europe has got used to British opposition and to making plans without the UK in the expectation it would join later," Major cautioned against always regarding the UK as a European integration laggard. As he put it, "Britain didn't just want to join the train. It wanted to be in the driver's cabin." UK governments may have been guarded about centre formation beyond the creation of the single market or co-operation using the Union method. None the less, their initial response to proposals for further integration was often to try to remain at the centre of the Union.

Their next-best was then to settle either for partial participation (Justice and Home Affairs) or for options to participate at future moments of their own choosing (monetary union). But why interpret these as constructive forms of differentiation? First, and most obviously, other member states were able to integrate further without having to step outside the EU Treaties in order to circumvent a British veto. Indeed, the idea - pioneered in response to British membership - that differentiation is the way of reconciling disagreements between those who want to integrate further and those who do not, seems likely to outlast British membership itself. "Coalitions of the willing" in which "new groups of member states agree on specific legal and budgetary arrangements to deepen their co-operation in chosen domains" form one 
scenario in the Commission's (2017: 20) recent White Paper on "the Future of Europe" after Brexit.

Second, British governments were often supportive even where they did not fully participate. When the exchange rate mechanism collapsed in 1993 it was the British finance minister who proposed the compromise of relaxing the mechanism but not abandoning it in ways which would have put the Treaty commitment to monetary union in question. Nor was that just an isolated example. The UK was too embedded in the Union's overall political economy for it not to have an interest in the stability and success of even those policies of which it was not a full member. Cameron's noisy veto in 2011 of the inclusion of the Fiscal Compact in the Union Treaties obscured the quieter assessment of his government that further integration of the eurozone needed the UK's support, given fragilities in its own banking system (Sandbu, 2015: 4).

Third, the UK sought to compensate for absence from some policies by commitment to others. Already in the early 1980s, Hill (1983) noted the "convenient schizophrenia" with which UK governments supported foreign policy co-operation whilst questioning the supranational policies and institutions of the then European Community. Later, by putting the UK at the core of the European Security and Defence Policy (ESDP), Blair hoped to offset its absence from monetary union (Liddle, 2014: 113).

\section{Crisis and Brexit: 2008-}

At the time of the 2004-7 enlargements and the Convention on the Constitutional Treaty, few would have regarded the UK's somewhat segmented relationship with the Union as a significant constraint on how far the British government could shape the membership, powers or institutions of the Union (Lord, 2008). It was a measure of the UK's influence as much as its awkwardness that, during the Convention, its President, Valéry Giscard D'Estaing, often asked the representative of the British Government to respond first to proposals (Norman, 2003). Fewer still would have predicted the UK might one day leave the Union. For all its difficulties, UK membership of the Union after 1973 had, in many ways, been remarkably successful. British Governments got much of they wanted from membership of the Union whilst avoiding almost everything they did not want. They secured both the single market initiative and the enlargement of the Union. When, however, invited to participate in monetary union and Schengen, the UK secured opt-outs. So extraordinary was the UK's ability to have its cake and eat it - to forge a relationship that was so bespoke as almost to amount to its own private form of membership - that the UK was able to opt out of large areas of Justice and Home Affairs, whilst securing rights to opt back in again to 130 or so specific measures. For sure, solutions such as these were complex. But they seemed to suggest that successful UK membership and further European centre formation could be combined. 
So, what went wrong? Structural and contingent factors - underlying weaknesses and events - interacted to unravel the UK's membership of the Union. Much changed as a result of 11 September 2001. Determined to demonstrate solidarity with the US, Blair committed the UK to the invasion of Iraq in 2003. That broke the New Labour voter coalition which otherwise had every chance of blocking the revival of the increasingly Eurosceptic Conservative Party. In retrospect, the UK Government also mishandled the 2004-7 enlargement by allowing unrestricted free movement without the normal 5-year transition. The Government predicted that as few as 12000 would move to the UK (Dustmann et al., 2003). More than 1 million did. For the first time, free movement became contentious in the UK. Later studies would find the Brexit vote was strong in areas there had been "a sudden influx" of EU-immigrants. In contrast, areas where EU-immigration into the UK had built up more slowly were pro-remain, even if the level of immigration was high (Goodwin and Heath, 2016).

Then, from around 2008 onwards, a plague of crises in European integration weakened UK membership further. The euro crisis did huge damage to the EU's reputation in the UK. Domestic support for UK membership had always been transactional. Few identified with the Union or valued European integration as an aim. But many accepted that a body such as the Union might be needed to deal with interdependence and cross-border problems. Many also accepted the UK needed a level of access to its largest and nearest market that could only be had from full membership of the Union. Hence, support for membership depended a great deal on the assumption that the EU contributed to the UK's economic performance. That confidence was weakened by the Euro crisis. In moving a Private Member's Bill that would have repealed the European Communities Act, Douglas Carswell - then still a Conservative MP - famously claimed that membership of the EU was like being "shackled to a corpse" (Daily Telegraph, 26 October 2012). By the end of 2012 , only $20 \%$ of UK public opinion had confidence in the EU against $69 \%$ who did not; only $29 \%$ agreed that the UK's "interests are well taken into account in the EU" against $61 \%$ who did not; $54 \%$ agreed that the UK "could better face the future outside the EU against $35 \%$ who disagreed; $80 \%$ were opposed to membership of the euro as opposed to $14 \%$ in favour" (Standard Eurobarometer, 81). So toxic had the euro become that, even in Scotland, supporters of independence in the 2014 referendum tried desperately, and unconvincingly, to argue that Scotland could easily join the EU without committing to the euro.

As well as weakening public confidence in the EU, the financial crisis also threatened the delicate balance the UK had achieved through its somewhat segmented membership of the Union: namely, the balance between participation in the single market and abstention from further integration. Monetary union, it was now believed, would need to develop further if it was to survive at all. In contrast to the Maastricht model in which complete centralization of monetary policy was balanced by near complete fiscal decentralization (De Grauwe, 2016: 151), the Eurocrisis 
made it likely that members of monetary union would need to accept more fiscal co-ordination and a banking union.

That, many in the UK feared, would either force the UK to join the Euro or risk domination by a eurozone majority in decisions of the wider European Union. Here the UK faced an acute dilemma. For it was, in a sense, anything but a monetary union "out." Since 1998, London has developed as the financial centre for the euro without being in the euro (Jones, 2015). It dominated both euro currency and bond trading. It headquartered most non-EU banks within the Union's single financial market. British Governments have, therefore, worried about institutional incongruence between the European Union and its monetary union. Many rules that govern access to the euro's financial infrastructure (Armstrong, 2016: 34) - clearing and liquidity - can (unsurprisingly) be made by euro-zone actors alone. Other financial regulations can be made as single market rules by the EU-28. Amongst the EU-28, the Eurozone-19 approximate on their own to a qualified majority of 55\% of member states representing $65 \%$ of the Union population. Hence, when asked to agree changes to the European Banking Authority (EBA), the UK insisted that the EBA should only be able to take decisions with a double majority of both eurozone "ins" and "outs." Hence, also a series of cases in which the UK has challenged EU financial regulation in the Court of Justice of the European Union. Hence finally, the inclusion in Cameron's attempted renegotiation of UK membership in February 2016 of a safeguard mechanism for non-eurozone member states (House of Commons, 2016: $13)$.

However, the financial crisis would not have been fatal on its own to UK membership. The prospect of a referendum being held on the UK's membership of the Union - made certain by the unexpected success of the Conservatives in securing an absolute majority in the May 2015 election - briefly turned opinion round in favour of remaining within the Union. In June 2015 remainers led leavers by $61 \%$ to $27 \%$ in an IPSOS-Mori poll. Yet by December 2015 that lead had disappeared again. An ICM poll had remainers and leavers almost tied at 42 to $40 \%$. The migration crisis of summer 2015 undermined the majority for remaining. It reinforced the belief that the EU was a dysfunctional body that had taken away the powers of member states to make their own laws and manage their own boundaries without adding new protections. Although, of course, the UK was not a part of Schengen, it was easy for some opponents of remaining in the EU to frame the migration crisis as a threat to the UK by arguing that asylum seekers accepted into the EU could eventually end up in the UK under free movement (Time Magazine, 16 December 2015).

Whilst, however, multiple crises of European integration fragmented UK membership after 2008, there were structural weaknesses in UK membership which made it vulnerable to those crises. For sure, the UK, as seen, got much of what it wanted from EU membership and avoided much of what it did not want. Yet, UK membership was as much a domestic failure as it was an external success. Externally the UK state adjusted well to membership. As seen, its civil service had a formi- 
dable reputation for its handling of EU meetings. Data on voting in the Council of Ministers showed that the UK was just like most other member states. In other words, British Governments hardly ever felt any need to vote against Council decisions (Mattila and Lane, 2001; Mattila, 2009; Hosli et al., 2011). Yet, domestically, British politics have never been well adjusted to its membership of the Union. Eurobarometer has often found low levels of identification with the Union; and, above all, a public opinion that, in almost all its surveys, turned out to have the least knowledge of the EU. Then, of course, there was the relentlessly negative framing of the EU in the UK media. de Wilde et al. (2013) explain the significance of that. As they put it, media research demonstrates that media reporting styles have a "direct impact on levels of Euroscepticism." In particular, where "EU reporting is not framed in a suggestive manner...cynicism about EU affairs decreases" (180). But UK Governments would probably have been more courageous in challenging misrepresentations of the EU had it not been for something else. In a system of just two main political parties that alternate in government, it mattered that those parties were never completely united, and sometimes deeply divided, within and between themselves on UK's membership. British Governments often responded by obfuscating Union issues, rather than explaining and justifying them (Lord, 1993). Sometimes they even mobilised opposition to the EU. The unwillingness of British Governments to own up to EU policies they had themselves agreed, shaped, and even encouraged made it more likely that Union decisions would be perceived as external impositions.

Yet, in spite of the structural weaknesses in the domestic political foundations of the UK's membership of the Union, public opinion on questions of European integration was, as seen in this section, often volatile between 2008 and 2016, rather than set on any historically inevitable path to Brexit. However, the referendum may itself have created precisely the deep and enduring divisions it was supposed to avoid. Before the referendum it was often said that - although usually unpopular European integration was not salient in British politics (Geddes, 2013: 245). In public opinion surveys, it was rare for the European Union to rank higher than the issue of third or fourth importance. The referendum has changed that. $63 \%$ of respondents in a YouGov survey ranked "leaving the European Union" as one of the three most "important issues facing the country." That was way ahead of what was considered by next most important issue: namely, health on 38\%. Moreover, that same YouGov survey confirms many others which show that a year on from the referendum there has been hardly any movement of opinion. A mere $5 \%$ of leave voters now think that the decision to leave was mistaken and a mere $5 \%$ of remain voters now think that the decision to leave was right. In place of the volatility noted earlier, the referendum would seem to have crystallised opinion into two equal and opposite camps. 


\section{Four Pasts and Four Futures?}

There is little chance that the 2016 referendum will bring any certainty to the UK's relationship with European integration. All we can say for certain is that voters were asked the following question: "Should the United Kingdom remain a member of the European Union or leave the European Union?" 51.9\% of voters then replied "leave" and $48.1 \%$ "remain." In contrast to other systems - such as several US states where those seeking change through a referendum often back up a short referendum question with a more precisely specified proposal of up to 10 pages no one specified a plan for delivering the referendum outcome. For sure, it seems reasonable, as seen, to assume that most leave supporters voted in some way to regain control of the UK's laws, money and boundaries. But it is less clear what leave voters understand by regaining control. 5 months after the referendum $90 \%$ of British voters - and, therefore, by implication, almost all leave voters - still supported access to the EU market (Curtice, 2016). Yet, access to the EU market can mean many different things. Norway, Switzerland, Canada, and the US all have access to the EU market in different ways, depending precisely on how those states relate their control of their own laws, money and boundaries to the defining feature of the EU's single market as a massive undertaking in shared law-making between EU members aimed at removing legal obstacles to trade behind boundaries.

In any case, Brexit cannot be fully defined without answering the question, exit to what? Yet, the alternative to UK membership of the EU will only be fully defined as the cumulative result of multiple further negotiations within the Union and beyond it. By some calculations Brexit "will require six interlocking sets of negotiations" (Grant, 2016). The UK will also need to decide what alternatives, if any, it will seek to the 759 international treaties in which it participates via its membership of the European Union (Financial Times, 30 May 2017). Above all, if it leaves the EU's customs union, the UK will also leave all 53 of its existing bilateral trading agreements that go beyond World Trade Organisation (WTO) rules.

Yet rebuilding the UK's bilateral trading relationships from zero will not just depend on what is negotiable with other states in the international system. The unknowns of international negotiation and the unknowns of British domestic politics are likely to feed on one another. Each choice of how the UK should structure its trading relationships after Brexit will also be a choice about the nature of the UK itself. Remaining close to the rules of the Union's single market - for example, by aiming at high levels of regulatory convergence even without being a formal member of the single market - will foreclose at least some options for the kind of free trade agreements the UK would be able to seek with, say, the US, China or India. However giving different priorities to trade with like and unlike economies with neighbours and global partners - will require many choices that are likely to be contentious within the UK. When a country makes choices on any one of many matters on which the UK will have to decide as part of the process of leaving the EU - on the regulation of financial markets, on migration, on workers' rights, on food safety, on environmental standards, on medicines - it makes choices about the 
kind of society it wants to be. Perhaps the core difficulty is that Brexit was only won with the votes of those most opposed to openness to globalization (Hobolt, 2016). Yet Brexit can only be delivered by finding new means of remaining open to trade and possibly even movement of labour. I will come back to the perplexing question of whether there is a stable majority for any one approach to Brexit.

First, though, it is important to clarify what those approaches are. Given historic opposition to participation in shared European institutions or identities - and given that the leave vote in the 2016 referendum cohered around "regaining control" - it is important to compare alternatives to EU membership by just how far they would change the UK's relationship with any process of European centre formation. Consider Table 1. On its own, the table is banal and simplistic. However, once the history of the UK's relationship with the EU since 1950 is considered in any detail a striking pattern emerges. The UK has either aimed at cells 2 or 3 or ended up in one of them. Even when the UK was last "out" between 1950 and 1973, its governments did not want to be fully "out." Even when it was "in" between 1973 and 2016, it was rare for the UK to be fully in all Union policies. Hence, the diagonal formed by cells 2 and 3 has been the historically dominant axis in the UK's commitment to European integration. Understanding that is a good starting point for identifying the choices available to the UK after Brexit and for comparing how far they would change the UK's relationship with European centre formation.

Table 1 Four levels of participation in European integration

\begin{tabular}{|l|l|}
\hline 1. Completely in. & 2. In but not completely in. \\
\hline 3. Out but not completely out. & 4. Completely out. \\
\hline
\end{tabular}

In rejecting full membership in 1950, the British Government did not expect to be completely outside any European Coal and Steel Community. It wanted to be "associated with the proposal" and expected to have substantial influence without full membership. As a government working party put it, "even as non-members our bargaining power and goodwill would be considerable... Some of the advantages of membership would come to us without being a member." ${ }^{10}$ From 1953, the UK was associated and in 1961 it applied for full membership of the European Communities.

If, however, British governments did not intend to be completely "out" before 1973, after that they rarely managed to be completely "in." Only occasionally during their membership did they satisfy an expectation at the time of their joining that all members should aim to participate in all policies. In the space of just 40 days in 1972, the UK first joined and left the EC's common currency float. This was no minor detail. It was precisely on the UK's ability to participate in monetary integration that the French President, Georges Pompidou, had sought - and received reassurances before agreeing to lift his veto on UK membership just a year earlier (Lord, 1993: 72). Moreover, on matters of monetary integration the UK would drift ever further apart from many of its new partners over the next forty years. Only for two disastrous years (1990-2) would the UK be full members of what was then the main mechanism of monetary integration: namely the exchange rate mechanism 
(ERM) of the European monetary system (EMS). Later, of course, it would also opt out of monetary union itself.

Given that the UK is opted out of Schengen as well as monetary union, it plainly starts Brexit from cell 2. Hence, Brexit would most likely move the UK from cell 2 to cell 3 or 4 . Improbable, though by no means entirely absurd, is the remaining possibility that Brexit could even move the UK in the direction of cell 1 . Each of those scenarios would mean different things for the UK's continued relationship with EU centre formation.

Scenario 1. Participating as a non-member (From cell 2 to cell 3). Schimmelfennig et al. (2015: 767) have distinguished between "internal differentiation where at least one member state does not participate in integration and external differentiation where at least one non-member state participates." One scenario is that Brexit moves the UK from the group of EU members which practices some form of internal differentiation to the group of non-member states which practices some form of external differentiation. Given deep and complex human, economic and security interdependencies with the EU, the UK may want to continue to participate in some Union policies. Several leavers have themselves variously supported continued market access, continued security co-operation, continued research collaboration, and even some continued labour and capital mobility.

However, ceasing to be a member - but continuing to participate in selected Union policies - would not necessarily insulate the UK from European centre formation. Forms of external differentiation differ precisely in how far they entail continued exposure to European centre formation. Some arrangements could even increase the UK's exposure whilst decreasing its decision rights over aspects of European centre formation (Eriksen and Fossum, 2015). There are two main existing models for non-member state participation in selective Union policies. First the Norwegian model based on the multilateral European Economic Area (EEA) agreed between three members of the European Free Trade Area (EFTA) - Norway, Iceland, and Liechtenstein - and the EU. Second, the Swiss model based on bilateral treaties (CEPR, 2013; Eriksen \& Fossum, 2015; Gstöhl, 2015). Both are "coming together" - as opposed to "falling apart" - forms of external differentiation (Leruth and Lord, 2015). That is, they were designed to allow states which have never been full members to participate in selected Union policies. How far they can be extended to states leaving the Union depends on how compatible they are with the reasons a state has for exiting in the first place.

Assuming the UK is leaving to regain control of its own laws, the Swiss model might seem far more compatible than the Norwegian with the UK's reasons for exiting. Since the EEA is a dynamic arrangement with a procedure for up-dating commitments to take account of new Union legislation and ECJ rulings, and Norway has 15 more agreements with the EU additional to the EEA, Norway has ended up by applying $75 \%$ of Union law. It has "taken some 8000 legal acts altogether from the EU" (Austvik, 2017). 
So how far can EEA countries control those Union laws they end up applying? As non-members, they cannot have decision rights in the making of Union law. However, they can decide not to incorporate a Union law into the EEA; and any of their national parliaments can refuse to ratify any incorporation. Yet - as Jónsdóttir (2013: 67) of the EFTA secretariat has explained - those mechanisms do not confer much "real veto power." Each EEA government and parliament knows that - under A102 of the agreement - the EU can respond to any refusal to incorporate EEA legislation by suspending that part of the EEA to which it relates. However, Jónsdóttir notes, "there is a real fear that the entire EEA agreement would collapse were A102 ever to be used. Given the EEA countries would then lose their automatic 'access to the single market' it is 'difficult if not impossible to say 'no' to EU legislation'" (ibid.). Likewise, arrangements for the uniform interpretation of EEA law have worked through Norway, Iceland and Liechtenstein establishing their own EFTA Court which is then expected " "to accord' judicial pre-eminence to the European Court of Justice without making that explicit" (Cremona, 1994: 517, cited in Fredriksen, 2015: 104). Perhaps, then, the Centre for European Reform (2014: 12) is justified in describing the EEA as "regulation without representation."

In contrast, the Swiss model would seem more suited to a country leaving the Union to regain control of its laws. Following the Swiss model would only put the UK under obligations to adopt EU law in so far as the British government and British parliament decide in static bilateral treaties that can only be changed (or superseded) by another bilateral treaty also agreed by the UK Government and Parliament. However, there would be two difficulties. First, the Norwegian model would keep the UK more convergent with single market rules and provide a credible commitment to continued convergence. Producers and investors would be able to make long-term commitments knowing that British government is committed by treaty to a procedure aimed at real-time convergence in regulations. Second, Switzerland has less practical autonomy than formal sovereignty in its approximation of many Union laws. In practice, Switzerland has to adopt much EU law unilaterally if it is to ensure legal and market certainty. Hence, an all-party report of the Foreign Affairs Committee of the House of Commons rejected the Swiss, as well as the Norwegian, model as "appropriate" for the UK. As the committee put it, "in both cases, the non-EU country is obliged to adopt some or all of the body of single market law without the ability to shape it" (House of Commons 2013, para. 164). Indeed, it is even arguable that a non-member seeking to maximise control of its own laws would be better adopting the Norwegian and not the Swiss model. Lavanex and Schwok (2015: 49) put the point well:

in practice (the Swiss) bilateral agreements have generated obligations similar to the EEA agreement. Even though Swiss adaptation to EU regulations is for the most part not the result of the incorporation of EU legal acts...but of the voluntary alignment of Swiss legislation with EU standards strong functional pressure for voluntary alignment is a structural fact...The negotiated, static and non-enforceable character of (Swiss 
commitments) have increasingly become artefacts in what de facto is a much more dynamic form of association.

Yet, a formal and multilateral commitment between the EEA and the EU to seek convergence of laws has the important advantage over any unilateral approximation of laws that, unlike Switzerland, the EEA countries "have a right to be consulted by the Commission during the formulation of Community legislation" (Austvik, 2017), which in practice means that EEA countries participate alongside full member states in EU committees which prepare proposals.

Still, many leavers would argue that the uniqueness of the UK's position cannot be understood through comparisons with Norway or Switzerland. One essential difference is that on the day of leaving the EU, the UK would start off fully convergent with single market legislation. Hence, the cabinet minister responsible for negotiating new trade agreements beyond the Union has argued that any trade agreement the UK concludes with the Union "should be one of the easiest in human history" (Financial Times, 20 July 2017). Moreover, leavers continue, every day after Brexit, the UK and EU would still have a shared interest in maintaining much of the convergence in their laws on the day of divorce itself (Legatum, 2016). Mutual recognition and voluntary convergence should be able to do much of the work without compromising anyone's formal rights to make their own laws.

Nor, need Brexit be constrained by existing procedures or power relations. The UK will not be constrained to choose either the Norwegian or Swiss model if Brexit itself reconfigures the power relations on which those models are based between the EU and those states in its neighbourhood which are unable to join the Union. Subtracting the UK from the EU's members - and adding it to those non-members which co-operate with it - could create a new equality between the EU's "ins" and "outs." Norway, Switzerland and a handful of others may, on their own, be condemned to be structure takers on matters such as market regulation. With the UK, the "outs" could, in the view of many Brexiters, be structure-makers, given the importance of the UK's economy and its contribution to European security. Perhaps a small sign of how Brexit could improve procedures for the participation of nonmembers in Union decisions is the proposal from the Bruegel Institute for a new continental partnership with a Council of Ministers for non-members. That Council, Bruegel suggests, should be able to propose, but not insist on, amendments to draft Union laws (Pisani-Ferry et al., 2016).

Scenario 2. Completely out (from cell 2 to cell 4). In 2014 the Institute of Directors ran a much-publicised essay competition for how the UK Britain should exit the European Union. Significantly the prize was won by a submission - that like the House of Commons report above - argued that the Swiss bilateral treaties would be a commitment too far for the UK (Mansfield, 2014. See also Bootle, 2014). Rather, the submission argued, if the UK wanted to avoid entanglement in EU regulation it should only seek an agreement of a kind any state in the international system - say Canada or Japan - might have with the EU. A determination 
only to seek agreements of a kind any third state might have with the EU seems to me as good a definition as any of an intention not to be a part of a specifically European project of integration. It would, arguably, also be the least ambivalent British policy towards European integration since 1950.

Yet, it is important to understand how different were the two periods of British ambivalence - the period from 1950 to 1973 when UK governments sought to be "out without being completely out" and the period from 1973 to 2016 when somehow the UK never quite managed to be "completely in even when it was in" - if we are to appraise what may now follow from avoiding any ambiguity at all by only seeking a relationship any state in the international system might have with the EU. Just as attempts to abstain from selective Union policies worked remarkably well once the UK was a full member between 1973 and 2016, attempts to influence and participate selectively failed when the UK was last a non-member between 1950 and 1973. The association agreement with the European Coal and Steel Community (1954) was a disappointment. As Northedge (1974: 155-6) put it, the agreement "merely provided for a Standing Council of Association for consultative purposes only." The UK's attempt to negotiate a wider European free trade area - that would allow the UK free trade without membership of the European Communities - was rebuffed in 1958. By the time the British Government applied for full membership in 1961, it had reached the conclusion that the UK could not afford to have access to continental markets on anything less than the best terms available.

Before that is dismissed as more ancient history, I suspect there are structural reasons why it is harder for non-members to participate selectively in Union policies and institutions than it is for members to abstain selectively from those policies. First, member states have formal veto powers. They can insist on selective rights of non-participation as a condition for not vetoing treaty changes. Second, even where their membership is full of exceptions, full members remain nested in the Union's overall authority relations. They can grant one another exceptions of infinite and dazzling complexity precisely because they are mutually committed to recognise the ultimate supremacy of a shared treaty, law and court in adjudicating where those exceptions begin and end.

Hence, in terms of table 1, it may be a mistake to under-estimate the difference between cells 2 and 3. Understanding the extent of the difference between cells 2 and 3 may, in turn, be crucial to any choice between cells 3 and 4. Quitting cell 2 for cell 3 may already entail high costs and difficulties before any assessment is made of what cell 4 would entail. Economists, lawyers and political philosophers might all have reasons to expect external differentiated integration to be more difficult than internal differentiated integration: to expect participating selectively as a nonmember (cell 3) to be harder than abstaining selectively as a non-member (cell 2).

For an economist, a body such as the EU is a provider of club goods. Think of swimming pools. Anyone has a choice between a) having no access to a pool; $b$ ) building her own swimming pool or c) paying a subscription along with many other people to a pool where they can all swim. But c) is only possible if those who do 
not pay the subscription - and accept all the other inconvenient rules that may be required to run the pool - can be excluded. Being able to exclude is an existential feature of the club. It can only exist so long as it can exclude those who won't pay its fees or obey its rules, rather than extend those benefits in a free ride to outsiders.

For a lawyer the problem goes deeper. The Union is not just a provider of club goods. It is a provider of club goods through laws its members make together. As a club aimed at removing non-tariff barriers so that all members can enjoy the shared benefit of just one legal framework for trading goods and services, the single market, as seen, is, of its nature, a giant undertaking in shared law-making. Yet, shared law-making presupposes legal certainty. Failure to provide uniform interpretation and application of law would undermine the whole purpose of the single market. Variations in interpretation and application would themselves be non-tariff barriers. Hence, member states have to commit to shared administration and adjudication of the laws they make together; and non-member states have, in turn, to decide how far they are going to take part in that shared administration and adjudication. Moreover, the likelihood there will be a trade-off between continuing to commit to shared administration and adjudication on the one hand and full convergence of laws on the other is not fully answered by the foregoing discussion of bargaining power between EU members and non-members. The problem is not just one of relative power. It is simply and straightforwardly a problem of what needs to be done to create a single market or at least remain convergent with it.

Political philosophers might go still further. It is not just the UK that needs to justify to its public that it has sufficient control of its own laws. Each of the 27 remaining members of the EU need to do the same. That might suggest three limits to the procedural inclusion of the UK in EU-law making after Brexit. First, limits to how far the UK, as a non-member, can even have informal veto powers if the EU is to have control of its own laws. Second, limits to how far the Union can precommit to any mutual recognition with the UK of market laws without the EU, once again, giving up control of its own laws. The Union might, most obviously, worry about forms of mutual recognition that would constrain its ability to make its own laws on product safety. Third, limits to how far EU procedures can be justified as a broadly fair way of making shared law between 27 closely interdependent democracies that have accepted the obligations of shared membership of the Union, if a non-member is allowed access to shared law-making without taking on the obligations and constraints of that shared law-making. When the EU insists there are limits to how far outsiders can participate in those of its policies that involve shared law-making it is not necessarily trying to dominate, exclude or even drive a hard bargain. Rather it is simply stating a truism that rights of participation in shared law-making must go with the obligations of shared law-making if those obligations are not to be subverted. Making shared law with other democracies within a mutually agreed set of rights and responsibilities that go with the coauthorship of laws just is a different relationship to bargaining with other states in the absence of shared membership of such a political and legal order. 
At this point many defenders of a clean-break Brexit - or moving to cell 4 rather than cell 3 in table 1 - might well find themselves agreeing with many defenders of European integration. Cell 4 is the solution that leaves everyone - the EU as much as the UK - with control of their own laws. Yet, as will be seen, the nature of the UK economy is as important to determining what forms of Brexit are feasible as conceptions of what it is for the UK to govern itself and make its own laws. Nor is it wise to assume that the eventual shape of Brexit will be intended by anyone. Any new relationship between the UK and EU could as easily be the product of accident and cumulative unintended consequences. It is easy enough to dismiss as absurd the possibility that the UK might leave the EU to regain control of its own laws just to sign up to an EEA-type arrangement. But the absurd remains possible. Neither a trade deal with the EU neither trade deals with the rest of the world - nor perhaps even full agreement on the UK's status as an individual member of the WTO - are likely to be concluded quickly. Trade agreements often take up to 7 years to agree and ratify. Few of any complexity have been concluded within the two years available to the UK after triggering Article 50. Hence, proposals for some temporary UK participation in the single market and customs union for some years after leaving. The obvious danger, however, is that a temporary solution would only perpetuate the crisis in the UK's relationship with the EU. Unless the UK really can conclude extensive trade agreements with the EU and beyond, it would face just the same predicaments at the end of a transition as it does now. It may, therefore, end up having to request that any transitional arrangements should be rolled over. The temporary would risk becoming permanent. Norway should know. It negotiated the EEA - which still defines its relationship with the EU - as a temporary measure in 1994.

Scenario 3. Completely in (From cell 2 to cell 1). In 2008, when it was still remembered that the banking crisis started in banks and blame had not yet been conveniently transferred to the euro, Wim Buiter, economist and member of the Monetary Policy Committee of the Bank of England, argued that the UK should join monetary union. His argument is worth quoting at some length. In Buiter's view, "the cost of a common currency - the loss of national monetary policy, that is, of the nominal exchange rate and/or the short-term risk-free nominal interest rate as possible policy instruments - is likely to be negative for the United Kingdom" (2008: 270). He then continued, "as regards cyclical convergence, the UK business cycle is now so synchronised with that of the eurozone that the country looks like a suburb of Frankfurt" (ibid.).

Moreover, Buiter continues, the UK does not just have a huge financial sector. Precisely because its position inside the single market has paradoxically allowed the UK to emerge as the financial centre of the euro-area, many of the financial assets and liabilities of the institutions for which the Bank of England is responsible are denominated in dollars or euros. That means the UK operates in the international financial system as a "giant floating hedge fund," taking in, and lending out, huge 
amounts in currencies other than its own. It also means that, in a financial crisis, the Bank of England would have to seek the help of the two central banks that have global currencies: namely, the United States Federal Reserve and the European Central Bank. No doubt, Buiter continues, it would be possible to arrange swaps "but there would be a cost" (op. cit.: 279). Those other central banks would have to charge a sufficient interest rate to cover the risks of lending to the Bank of England in a crisis. Now, clearly the UK state stands behind the Bank of England. But that is only a help in so far as the British state is:

capable of making both the internal fiscal transfer (from taxpayers to the
state) and the external transfer (from domestic to foreign residents) required
to service any additional debt ... Given the size of the external liabilities
of the United Kingdom and given the size of the foreign currency
liabilities of the UK banking sector, the ability of the state to provide a
credible guarantee for the survival of the UK banking sector cannot be
taken for granted (ibid.).

So, as little as ten years ago, there were some albeit lonely voices, urging the UK not to exit the Union, but to dive deeper into it by joining monetary union. Buiter's deeply unfashionable analysis, I think reminds us of a broader difficulty. The only thing sillier than a deterministic view of international systems, is surely a belief those systems can be ignored. The contemporary demands of economic and security systems have often counted for more than historic reticence towards European centre formation in defining British policy towards European integration. First to go was British opposition to any concentration of power on the near continent. By 1950, the British Foreign Office felt that intervening "to prevent progress to a West European Federal system" would "incur the utmost political odium." Defence felt that "any failure to give effect to the Schuman proposals would amount to a setback in the cold war." 12 If, in the 1950s, UK policy to European integration had to be adapted to geopolitical competition, in the 1980s it had to be adapted to global economic competition and a perception that the UK and its neighbours needed to develop their competitive advantage in a shared internal market - free of any crazy patchwork of multiple laws and multiple fixes for favoured producers - if they were to cultivate the high-value added economies needed to sustain their expensive societies. That leads me to one final heretical thought. If the UK participates in the EU because it is located where it is in international economic and security systems, it may fail to exit the European Union other than cosmetically. We have seen - and will further see - that neither the UK economy, nor the UK state, nor even the UK political system can easily extricate itself themselves from membership of the European Union. Yet, failed exits are important moments in the formation of Federations. Once exit - and perhaps even non-cooperation are no longer plausible choices voice within a shared political order and loyalty to it may be amongst the only remaining options (Hirschmann, 1970). Could Brexit end up as a milestone in European centre formation? 


\section{Can the UK Decide?}

Ways in which Brexit might further fragment the Union need little repeating here. They include risks that other governments may attempt to get what they want by threatening to leave; or that the Brexit vote may be just an episode in a wider populist insurrection against the established elites and institutions of representative democracy. Then, there are risks that Brexit will be lose-lose for both the UK and the Union. Take, for example, the UK's position as a European financial centre. Finance works by clustering. Positive externalities accrue from conducting many different kinds of financial transaction in one place. Putting London outside the single financial market may also be a negative shock to the Eurozone economy. It may increase financing costs of both EU Governments and EU banks. Hence, the Euro could itself even be a casualty of Brexit. In Europe's cascade of crises, the crisis in monetary union may have fed the Brexit crisis, which may, in turn, feed back into a further crisis in the single currency.

What, though, of the risks of Brexit to the UK itself? Brexit may even turn out to be both necessary and impossible: something that the British Government must do and cannot easily do. The UK Government has received a clear instruction from the electorate to leave the European Union. However, any one of leaving the single market, leaving the customs union or ending free movement could inflict great damage on the British economy (CEPR, 2016). The UK runs a large balance of payments deficit. Its public finances remain vulnerable to a long economic downturn. It has an accumulated stock of 1 trillion dollars of foreign direct investment, ${ }^{13}$ much of which only came to the UK to access the EU's single market. Although the UK's banking system is much stronger than 5 years ago, the IMF reminds us that: "the UK is at the core of the international financial system, being both home and host to so many systemically important financial institutions. The effectiveness '...of its framework for managing the stability of its banks...' will, therefore, depend on strong cooperation with other countries" (2016: 5). The Bank of England observes that UK banks remain vulnerable to high levels of mortgage debt which could go bad in a downturn or with higher interest rates and risk premia on British assets (2016: 10). The National Institute for Economic and Social Research points out that the British financial sector does not just depend on access to the single market, but on access to Euro clearing and currency swaps (Armstrong, 2016: 34).

The political and legal difficulties of disentangling the UK from its membership are no less acute. On average around $20 \%$ of law in member states is European Union law (Töller, 2010). 6000 EU laws are applied in the UK under the European Communities Act (ECA) of 1972. Thus, the first thing the UK may need to do on repealing the ECA and leaving the EU is to dive straight back in again by adopting all EU law into UK domestic law. Otherwise, it has been noted, every financial trade in the City of London would lack legal certainty or be outright unlawful (Legatum, 2016). Still, the UK will eventually need to review EU laws to decide which to retain. If it takes a light touch, the UK will continue, in some significant part, to be governed by EU laws. Reviewing and changing much EU legislation could, con- 
versely, take years. It could also create constitutional difficulties. To expedite matters the Government may want to change EU law by executive discretion: by what are ominously known in the UK as Henry VIII clauses. Parliament, in contrast, is likely to object to up $20 \%$ of law being redefined by the executive acting with minimal parliamentary involvement. However, even before it repeals the ECA, the UK may encounter another constitutional crisis. Repeal will require amending the legislation establishing the devolved assemblies of Scotland, Wales and Northern Ireland. But, UK constitutional convention, ${ }^{14}$ such as it is, holds that devolution legislation can only be changed with the agreement of Edinburgh, Cardiff or Belfast.

Worse, Brexit may destabilize the UK political system. Some 30-50 years ago many political scientists identified a central mystery of the British political system: why, they asked, was the UK system so widely accepted when it usually allowed just one party - sometimes with much less than $50 \%$ of the vote - to exercise power on its own for up to 5 years? Amongst answers were the following. First, the UK was an unusually homogenous society (Finer, 1970: 131). Second, British parties competed for the centre. The exclusion of all but one party from power could still, as Lijphart put it, approximate to "government by the people" (1984: 22) if even those who voted for other parties felt served by the one party that ended up in government. Third, although a state of four nations, territorial cleavages in British politics, were weak, with the exception of Northern Ireland which was small and largely peripheral to the allocation of power within the British political system. Otherwise, territorial differences - and, indeed, many other possible divisions in British politics - were subsumed into a single left-right dimension of political competition (Harrison, 1996). Yet, fourth, that single left-right dimension was as weak as it was unifying. Leftright, and sociological class-based voting, dominated not because left-right ideologies were important to anyone but a few, but in the near absence of much else to argue about (Butler \& Stokes, 1969). The UK enjoyed the benefits of a simple onedimensional structure of political competition without polarisation and without smothering other forms of political choice. Fifth, it followed that the UK avoided the dangers a more multi-dimensional form of political competition would have posed for a political system that allowed mere pluralities to exercise so much power on their own. Where choice is multi-dimensional, yet the system majoritarian, mere pluralities cannot just govern to the exclusion of others. They can also make arbitrary choices by merely deciding which options are to be considered in which sequence (Riker, 1982).

All the foregoing conditions for the stability of the British political system were already eroding well before Brexit. Indeed, Brexit itself is both a product of breakdown in the British political system, and a likely source of further crisis within it. Far from being homogenous, the UK is now one of the most unequal societies in Europe. Part of the Brexit vote, especially in the north of England, can be explained by that inequality. ${ }^{15}$ Using data from the British Election Survey, the Joseph Rowntree Foundation has shown that "groups vulnerable to poverty were more likely to 
support Brexit...There is a strong relationship between household income and support for leave" (Goodwin and Heath, 2016).

Second, newly acute territorial cleavages within the UK are likely to multiply the difficulties of handling Brexit. Two of the four nations of the UK voted for Brexit and two against. Of the two that voted for Brexit, one (Scotland) is itself divided on whether it should remain in the United Kingdom. The other (Northern Ireland) is only recovering from decades of civil conflict with the help of a peace process which could itself by disrupted by Brexit. Yet, any form of Brexit that takes account of the special circumstances of Scotland and Northern Ireland is only likely to sharpen the contradictions between different forms of Brexit. Take the example of Northern Ireland, which could yet turn out to be one of many problems on which Brexit unravels. The recreation of a physical boundary between the United Kingdom and the Republic of Ireland could risk much of what has been achieved by the Anglo-Irish agreement (1986) by creating an impression amongst the "nationalist" community in Northern Ireland that it is bottled up forever in the United Kingdom. Yet, to avoid the need for a physical boundary, the UK would need to remain in a customs union with the EU. That, however, would be incompatible with the Brexiters' hope that leaving the EU would free up the UK to negotiate free trade agreements of its own all round the world. Moreover, without a physical boundary, the UK will only be able to reassert an imperfect control over free movement of persons from the European Union. Administrative checks within the UK itself on illegal entry by EU citizens would have to substitute for "at border" checks.

Third, in place of a one-dimensional structure of political competition, the UK now does not just have a territorial cleavage. It also has two distinct left-right cleavages: one preoccupied with markets, the other with immigration and identity. All that interacts with what is surely the most intractable feature of Brexit: namely, the difficulty of discerning any stable equilibrium within British politics for any one approach to leaving the Union. For some hard Brexit means open markets. The UK should leave the single market and the customs union to operate like a giant Singapore, with a zero-tariff regime and maximal deregulation. For others, though, hard Brexit means hard boundaries. Those ideas may not be easy to reconcile. Outside the Union, the UK will only prosper through maximum openness to global markets if the UK is open to whatever capital and labor flows are required by its complex supply chains and by the goal of keeping its economy at the cutting edge of international competition. Not only, though, do hard Brexiters form an inconsistent coalition. They also occupy strategically different positions within British politics. It is the market liberalisers who are able to threaten rebellion within the Conservative Party. It is the supporters of hard boundaries who form a large part of Brexit voters. Many Brexit voters from the north of England would be unlikely to agree with the former chair of the leave campaign that Brexit was a vote to complete the Thatcher revolution (op. cit.: 4). Yet, however, contradictory the Brexit coalition, it may come together again to oppose many of the trade-offs that may be needed for a soft Brexit. 
Fourth, the UK is now divided by generations. Indeed, just as with other differences, the Brexit vote is both product and cause of generational differences. Barnett (2017), founder of the campaign group Open Democracy, has described Brexit as an "old people's home." In his view, Brexit is "government of the old, by the old, for the old." As Barnett observes, opinion surveys find no majority for Brexit in any age group "under the age of 55." In a YouGov (2017) survey in March 2017 only $12 \%$ of the 18-24 age group thought that Brexit was "right." 65\% thought it "wrong."

Further referendums and general elections may be needed to decide the form of Brexit. Yet going back to the people may not produce an answer either. Curtice (2016) identifies the problem in the most extensive survey of UK public opinion following Brexit:

\begin{abstract}
Voters cannot simply be divided into those who want a 'soft' and those who want a 'hard' Brexit. In fact, key elements to both approaches are supported by a majority of voters... On the one hand, there is near universal support for maintaining free trade between the UK and the EU...On the other hand, about seven in ten voters believe that the UK should be able to control immigration from the EU.
\end{abstract}

Once, however, voters are asked which they would support if a choice really had to be made between those options, opinion remains every bit as divided as it was in the referendum itself. As Curtice continues, "if people are asked whether the UK should allow EU migrants to come here if this were the only way UK firms could trade freely with the EU, 49\% say that the UK should definitely or probably allow free movement, $51 \%$ said that it should probably or definitely not." As seen, the two camps show signs of hardening into equal and opposite forces in British politics.

In sum, the predicament is something like this: only by offering choices that explicitly trade off the two left-right cleavages - the identity cleavage and the open market cleavages - can even English opinion decide what it wants from Brexit. Any attempt to decide the form of Brexit on market or identity considerations alone would be bound to be seen as arbitrary by the losing minority. Yet, any feasible trade-off between the cleavages would be likely to split English opinion a second time. And, beyond England, there may, in any case, be few forms of Brexit that will work for all parts of the UK.

\title{
7. Conclusion
}

Some thirty years ago, a common historical interpretation held that the UK was the EU's "Awkward Partner." I have argued here that the domestic politics of UK membership were certainly awkward. Yet, for the most part, it was, until 2016, possible to reconcile British membership of the EU with continued European integration. Even now it remains unclear what will follow from the vote to leave the EU. The referendum was not accompanied by a clear plan for leaving the 
Union and none has emerged since. It is possible that there simply is no exit option that the UK can achieve at acceptable cost. Given that the UK is so much a part of the European economy and of the European security order, it seems hard to believe that the UK will not be deeply affected by any further European integration. Yet, participating in selective EU policies as a non-member state is likely to be much more difficult than abstaining from selective policies as a full member. Those difficulties are compounded by the absence of any stable majority within British politics for any one approach to Brexit. Worse, the attempt to withdraw the UK from the EU may destabilise the British political system itself. Unable to decide the nature of its exit, what passes for Brexit may eventually be decided by others, notably the EU itself. Indeed, Brexit may continue to be more accident than design. Even in making any offer of their own to the UK, the institutions and other member states of the Union may themselves only stumble on a long-solution by offering a transitional arrangement that happens to become permanent. Likewise, the UK may stumble on a long-term solution through practices that depend on unilaterally approximating the very EU laws it pretends to be leaving. Exiting to regain control of its own laws, may yet leave the UK with less control of its own laws than it had as a full member. The most absurd outcome of the June 2016 referendum remains one of its most likely outcomes.

\section{NOTES}

1. As a meeting of the Permanent Under-Secretary's Committee of the Foreign Office concluded, "If the views of the majority and the United Kingdom did not coincide, the United Kingdom might find it hard to remain in any organisations where federal ideas and federal solutions were consistently imposed by a majority," Public Record Office (PRO) ZP 18/19, Memorandum of the Permanent Under-Secretaries Committee, 13 February 1951.

2. PRO CAB 134/295 "Constitutional problems involved in a supranational authority as proposed by M. Schuman," 16 June 1950. PRO ZP 18/20 Memorandum by Permanent Under-Secretary's Committee of the Foreign Office 9 June 1950.

3. PRO C(51) 32, "United Europe," Memorandum by the Prime Minister to the Cabinet, 29 November 1951.

4. Hansard, House of Commons Debates, 22 July 1971, Col 1906.

5. House of Commons Debates, 13 July 1972, Vol. 840, Col 1875.

6. See Aspinwall (2006) for evidence that, even as recently as the negotiation of the Amsterdam Treaty (1997), different framings of the lessons of the Second World War for European integration continued to influence the preferences of EU governments.

7. I thank David S. Bell for this wise crack.

8. H.P.Bulmer Ltd v. J. Bollinger SA (1974) Ch 401 at 418.

9. PRO CAB 128 17, Conclusions of a Meeting of the Cabinet held at 10 Downing Street on Friday 2 June 1950.

10. PRO F.G. (W.P.) (51) 43, Report of a Working Party Constituting the European Coal and Steel Community, 31 December 1951.

11. Makins to Strang, 28 June 1950, PRO [CE 3353/2141/181].

12. Memorandum by the Minister of Defence, 1 July 1950, PRO [CE 3452/2141/181]. 
13. Will Hutton, The Observer, 30 October 2016.

14. Memorandum of Understanding between the United Kingdom Government, The Scottish Ministers, The Welsh Ministers and the Northern Ireland Executive Committee (2012): "The United Kingdom Parliament retains legislative authority on any issue, whether devolved or not...However, the UK Government will proceed in accordance with the convention that the UK Parliament would not normally legislate with regard to devolved matters without the agreement of the devolved legislature." Paragraph 14. Available at www.gov.uk/government/publications/devolution-memorandum-of-understanding. Last accessed 17 November 2016.

15. See Bell and Machin (2016): "The spatial distribution of leave votes was correlated with low and stagnating wage levels." There is also a relationship between the leave vote and the 62 out of 370 local authorities where "real wages have fallen" since 1997.

\section{REFERENCES}

Armstrong, A. (2016). "EU Membership, Financial Services and Stability," National Institute Economic Review 236. London: National Institute of Economic and Social Research.

Ashcroft, Lord (2016). "How the UK Voted on Thursday and Why." www.lordashcroft polls.com.about. Last accessed 27 July 2017.

Aspinwall, M. (2006). "Government Preferences on European Integration: An Empirical Test of Five Theories," British Journal of Political Science 37(1): 89-114.

Attali, J. (1995). Chronique des Années 1988-1991. Paris: Fayard.

Austvik, O. G. (2017). "Norway and the European Economic Area. Good Deal or Just an EU Rule-taker." www.scer.scot/database/ident-1804. Last accessed 5 August 2017.

Bank of England (2016). Financial Stability Report No. 39. July, London.

Bell, B., and S. Machin (2016). "Brexit and Wage Inequality," in R. Baldwin (ed.), Brexit Breckons. Brussels: CEPR.

Bickerton, C. (2012). European Integration. From Nation States to Member States. Oxford: Oxford University Press.

Bickerton, C., D. Hodson, and U. Pütter (2015) (eds.). The New Intergovernmentalism. States and Supranational Actors in the Post-Maastricht Era. Oxford: Oxford University Press.

Bootle, R. (2014). The Trouble with Europe. London: Nicholas Brealey.

Buiter, W. (2008). "Why the United Kingdom Should Join the Eurozone," International Finance 11(3): 269-282.

Bullock, A. (1983). Ernest Bevin: Foreign Secretary 1945-51. London: Heinemann.

Butler, D., and D. Stokes (1969). Political Change in Britain, Forces Shaping Electoral Choice. Harmondsworth: Pelican.

Centre for Economic Policy Research (2013). Trade and Investment. Balance of Competence Review. London: CEPR.

Centre for European Reform (2014). "The Economic Consequences of Leaving the European Union," London: Centre for European Reform. http://www.cer.org. Last accessed 8 August 2014.

Colley, L. (1992). Britons. Forging the Nation 1707-1837. New Haven, CT: Yale University Press.

Cremona, M. (1994). "The 'Dynamic and Homogeneous' EEA: Byzantine Structures and Various Geometry,” European Law Review 19: 508-526. 
Curtice, J. (2016). What Do Voters Want from Brexit? London: National Centre for Social Research. www.whatukthinks.org/eu/what-do-voters-want-from-brexit? Last accessed 19 November 2019.

Curtin, D., and M. Egeberg (2008). “Tradition and Innovation. Europe's Accumulated Executive Order," West European Politics 31(4): 639-661.

De Grauwe, P. (2016). "The Legacy of the Eurozone Crisis and How to Overcome It," Journal of Empirical Finance 39: 147-155.

De La Serre, F. (1987). La Grande Bretagne et la Communauté Européenne. Paris: PUF.

De Wilde, P., A. Michailidou, and H.-J. Trenz (2013). Contesting Europe: Exploring Euroscepticism in Online Media Coverage. London: Routledge.

Dicey, A. V. (1885). Introduction to the Study of the Law of the Constitution. London: Macmillan.

Dustmann, C., M. Casanova, M. Fertig, I. Preston, and C. Schmidt (2003). The Impact of Enlargement on Migration Flows. London: Home Office Report.

Dyson, K., and K. Featherstone (1999). The Road to Maastricht. Oxford: Oxford University Press.

Eriksen, E.-O., and J.-E. Fossum (2015) (eds.). The European Union's Non-Members. Independence under Hegemony. London: Routledge.

Finer, S. (1970). Comparative Government. Harmondsworth: Penguin.

Flora, P., with S. Kuhnle and D. Urwin (1999). State Formation, National-Building and Mass Politics in Europe. The Theory of Stein Rokkan. Oxford: Oxford University Press.

Fredriksen, H. H. (2015). "The EEA and the Case Law of the CJEU. Incorporation without Participation," in E.-O. Eriksen and J.-E. Fossum (eds.), The European Union's NonMembers. Independence under Hegemony. London: Routledge, 102-118.

Geddes, A. (2013). Britain and the European Union. Basingstoke: Palgrave Macmillan.

Genschel, P., and M. Jachtenfuchs (2014) (eds.). Beyond the Regulatory Polity? The European Integration of Core State Powers. Oxford: Oxford University Press.

Grant, C. (2016). "Six Brexit Deals That Theresa May Must Strike," Prospect Magazine 28 July.

Goodwin, M., and O. Heath (2016). "Brexit Vote Explained: Poverty, Low Skills and Absence of Opportunities." www.jrf.org.uk/report/brexit-vote-explained. Last accessed 20 November 2016.

Gstöhl, S. (2015). "Models of External Differentiation in the EU's Neighbourhood: An Expanding Economic Community?," Journal of European Public Policy 22(6): 854-870.

Harrison, B. (1996). The Transformation of British Politics 1860-1995. Oxford: Oxford University Press.

Heath, E. (1970). Old World, New Horizons. The Godkin Lectures 1967. London: Oxford University Press.

Hill, C. (1983). "Britain, A Convenient Schizohprenia," in C. Hill and W. Wallace (eds.), National Foreign Policies and European Political Co-operation. London: Allen \& Unwin, 19-33.

Hill, C. (1993). "The Capabilities-Expectations Gap or Conceptualising the EU's International Role," The Journal of Common Market Studies 31(3): 305-328.

Hirschmann, A. (1970). Exit Voice and Loyalty: Response to Decline in Firms, Organisations and States. Cambridge, MA: Harvard University Press.

Hobolt, S. (2016). "The Brexit Vote: Divided Nation, A Divided Continent," Journal of European Public Policy 23(9): 1259-1277.

Horne, A. (1988). Macmillan 1894-1986. London: Macmillan. 
Hosli, M., M. Mattila, and M. Uriot (2011). "Voting in the Council of the European Union after the 2004 Enlargement. A Comparison of Old and New Member States," Journal of Common Market Studies 49(6): 1249-1270.

House of Commons (2013). "The Future of the European Union. UK Government Policy," First Report of Session 2013-4. Volume 1. London: House of Commons.

International Monetary Fund (2016). United Kingdom: Financial Sector Assessment Programme. Washington, DC: IMF.

Jones, E. (2015). "Forgotten Financial Union. How You Can Have a Euro Crisis without the Euro," in M. Matthijs and M. Blyth (eds.), The Future of the Euro. Oxford: Oxford University Press, 44-69.

Jónsdóttir, J. (2013). Europeanisation and the European Economic Area. Iceland's Participating in the EU's Policy Process. London: Routledge/UACES.

Lavanex, S., and R. Schwok (2015). "The Swiss Way: The Nature of Switzerland's Relationship with the EU," in E.-O. Eriksen and J.-E. Fossum (eds.), The European Union's Non-Members. Independence under Hegemony. London: Routledge, 36-51.

Legatum Institute (2016). The Road to Brexit. London: Legatum Institute.

Leruth, B., and C. Lord (2015). "Differentiated Integration in the European Union: A Concept, a Process, a System or a Theory," Journal of European Public Policy 22(6): 754-763.

Liddle, R. (2014). The Europe Dilemma, Britain and the Drama of European Integration. London: Tauris/Policy Network.

Lijphart, A. (1984). Democracies. Patterns of Majoritarian and Consensus Government in Twenty-One Countries. New Haven, CT: Yale University Press.

Lord, C. (1993). British Entry to the European Community under the Heath Government of 1970-4. Aldershot: Dartmouth.

Lord, C. (1996). Absent at the Creation. Britain and the Schuman Plan 1950-2. Aldershot: Dartmouth.

Lord, C. (2004). A Democratic Audit of the European Union. Basingstoke: Palgrave Macmillan.

Lord, C. (2008). "Polity Empowering or Polity Constraining? A Comparison of British and French Attempts to Legitimise the Constitutional Treaty," Journal of European Public Policy 15(7): 1001-1018.

Lord, C. (2017). "How Can Parliaments Contribute to the Legitimacy of the European Semester?," Parliamentary Affairs. doi:https://doi.org/10.1093/pa/gsx017.

Mansfield, I. (2014). A Blueprint for Britain: Openness, Not Isolation. London: Institute for Economic Affairs.

Marcussen, M., T. Risse, D. Engelmann-Martin, H.-J. Knopf, and K. Roscher (1999). "Constructing Europe. The Evolution of French, British and German Identities," Journal of European Public Policy 6(4): 528-544.

Massigli, R. (1978). Une Comédie Des Erreurs. Paris: Plon.

Mattila, M. (2009). "Roll Call Analysis of Voting in the European Union Council of Ministers after the 2004 Enlargement," European Journal of Political Research 48(6): 840-857.

Mattila, M., and J.-E. Lane (2001). "Why Unanimity in the Council? A Roll-Call Analysis of Council Voting," European Union Politics 2(1): 73-97.

McLaren, L. (2004). "Opposition to European Integration and Fear of Loss of National Identity. Debunking a Basic Assumption about Opposition to the Integration Project," European Journal of Political Research 43(6): 895-911. 
Norman, P. (2003). The Accidental Constitution, The Story of the European Convention. Brussels: EuroComment.

Northedge, F. S. (1974). Descent from Power. British Foreign Policy 1945-73. London: George Allen and Unwin.

Pisani-Ferry, J., N. Röttgen, A. Sapir, P. Tucker, and G. Wolff (2016). Europe after Brexit. A Proposal for a Continental Partnership. Brussels: Bruegel Institute.

Redwood, J. (2012). "This Realm of England Is an Empire.” www.johnredwoodsdiary.com/ 2012/06/07/this-realm-of-england-is-an-empire. Last accessed 14 July 2017.

Riker, W. (1982). Liberalism against Populism. A Confrontation between the Theory of Democracy and the Theory of Social Choice. San Francisco, CA: W.H. Freeman.

Risse, T., D. Engelmann-Martin, H.-J. Knopf, and K. Roscher (1999). "To Euro or Not to Euro? The EMU and Identity Politics in the European Union," European Journal of International Relations 5(2): 147-187.

Sandbu, M. (2015). Europe's Orphan, The Future of the Euro and the Politics of Debt. Princeton, NJ: Princeton University Press.

Schimmelfennig, F., D. Leuffen, and B. Rittberger (2015). "The European Union as a System of Differentiated Integration: Interdependence, Politicization and Differentiation," Journal of European Public Policy 22(6): 764-782.

Seldon, A., and G. Lodge (2010). Brown at 10. London: Biteback.

Simonian, H. (1985). The Privileged Partnership: Franco-German Relations in the European Community 1969-1984. Oxford: Oxford University Press.

Thatcher, M. (1993). The Downing Street Years. New York: Harper Collins.

Töller, A.-E. (2010). "Measuring and Comparing the Europeanisation of National Legislation. A Research Note," Journal of Common Market Studies 48(2): 417-44.

UK Government (2017). "The Government's Negotiating Objectives for Exiting the EU: PM Speech." www.gov.uk/government/speeches/the-governments-negotiating-objectivesfor-exiting-the-eu-pm. Last accessed 30 March 2017.

Vasilopoulou, S. (2016). "UK Euroscepticism and the Brexit Referendum," Political Quarterly 87(2): 219-227.

Weale, A. (2017). “The Democratic Duty to Oppose Brexit," Political Quarterly 88(2): $170-181$.

Weiler, J. (2005). "On the Power of the Word. Europe's Constitutional Iconography," International Journal of Constitutional Law 3(2/3): 173-190.

YouGov (2017a). "Brexit and Leaving the EU," www.yougov.co.uk/news/categories/ politics.

YouGov (2017b). Tracking Poll, 10-11 July. www.yougov.co.uk/results. Last consulted 17 July 2017. 
Reproduced with permission of copyright owner. Further reproduction prohibited without permission. 